\title{
The effect of enzyme and protein source on laying hens performance, eggshell and bone traits
}

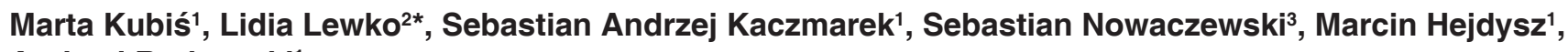 \\ Andrzej Rutkowski ${ }^{1}$ \\ ${ }^{1}$ Poznan University of Life Sciences, Department of Animal Nutrition and Feed Management, Wołyńska 33, 60-637 Poznań, ${ }^{2}$ National \\ Research Institute of Animal Production, Experimental Station Kołuda Wielka, Waterfowl Genetic Resources Station in Dworzyska, \\ 32-065 Kórnik, Poland, ${ }^{3}$ Poznan University of Life Sciences, Department of Animal Breeding and Product Quality Assessment, Złotniki, ul. \\ Słoneczna 1, 62-002 Suchy Las, Poland
}

\section{A B S T R A C T}

The aim of the study was to investigate the interaction between exogenous phytase with protease and protein source in laying hens diet. A completely randomised design study with a $2 \times 4$ factorial arrangement was conducted to observe effects of protein source (soybean vs. yellow lupine seeds diet) and enzyme addition (no enzyme vs. phytase or protease or both) on laying hens performance, bone mineralization and some egg traits. One hundred sixty Hy-Line Brown hens at the age of 18 weeks were weighed and randomly assigned to 10 treatments, each with 16 birds. According to the producer recommendation in diets containing enzymes reduced the level of available phosphorus (50\% reduction) and digestible amino acids - $5 \%$ reduction. The egg production during the entire experiment was similar in all groups without significant differences. The egg weight was also on an equal level in all treatments and it was about $58 \mathrm{~g}$. Birds fed different protein source were characterized by similar feed intake and feed conversion ratio during the whole experiment. The feed conversion ratio (FCR) was about 1.9-2.0 in all groups. Tibia ash was affected by enzymes supplementation. There was an interaction between protein source and enzymes addition. Birds from treatments fed with yellow lupine meal (YLM) diets reached highest tibia ash level in a group with phytase addition and in groups with SMB in a group with phytase and protease mix. The inclusion of enzymes improved the thickness of the shell. There was an interaction between protein source and enzyme inclusion. It was an interaction between experimental factors in shell breaking strength. Stronger eggshell was laid by hens from groups fed with the inclusion of yellow lupine meal. Addition of phytase had a positive impact on increasing the strength of eggshell. Only inclusion of enzymes affected significantly on shell elastic deformation in part I of eggs. Eggs from hens fed diets with inclusion of protease and phytase mix were most resistant to elastic deformation.

Keywords: Phytase; Lupines; Protease; Eggs; Tibia

\section{INTRODUCTION}

Soybean meal (SBM) is the best vegetable protein source used in livestock feed in the world. More than $50 \%$ of the world's protein meals is SBM. This is due to the relatively high content of crude protein $(\mathrm{CP})$ and very good amino acid (AA) profile and high digestibility of them (Ravindran et al., 2014). SBM has also ani-nutritional factors (ANF) like protease and trypsin inhibitors, that affects adversely on protein digestibility and AA availability (Jahanian and Rasouli, 2016). SBM is mostly genetically modified and many of customers all over the world does not accept the GMO products used in feed industry (Rutkowski et al., 2015). It is expected that in 2020 on the earth will live more than 10 billion people. This means increased demand for food which is associated with an increased demand for feed for livestock. For all this reasons it became necessary to find new and alternative protein source that could make up or replace SBM in poultry diets (Krawczyk et al., 2015; Mikulski et al., 2012) In recent years interest in use of homegrown legume like yellow lupine increased (Smulikowska et al., 2014; Viveros et al., 2007).

In the past use of yellow lupine in poultry diets was limited by the high alkaloid and non-starch polysaccharides (NSP) content which negatively affected on growth and production performance of birds (Kocher et al., 2000; Olkowski et al., 2001; Olkowski et al., 2005). Due to progress in plant

\footnotetext{
${ }^{*}$ Corresponding author:

Lidia Lewko, National Research Institute of Animal Production, Experimental Station Kołuda Wielka, Waterfowl Genetic Resources Station in Dworzyska, 32-065 Kórnik, Poland. E-mail: lidia.lewko@izoo.krakow.pl
} 
breeding, the level of antinutrients in lupine seeds had decreased, resulting in the development sweet lupines. Seeds of new Polish cultivars of yellow lupine characterized by high protein content $(38 \% \mathrm{CP})$, a low alkaloid content and high NSP concentration (Kaczmarek et al., 2014; Rutkowski et al., 2015). In recent years the use of lupine seed in the broiler (Hammershoj and Steenfeldt, 2005; Olkowski et al., 2005) and laying hens (Krawczyk et al., 2015; Liebert et al., 2005; Zdunczyk et al., 2014) has become popular. Studies are not conclusive about inclusion rate of lupine seed in poultry diets. Smulikowska et al. (2014) suggested that 15\% is optimum inclusion rate in broiler chicken diets. On the other hand, Orda et al. (2004) and van Barneveld (1999) used 25-30\% without a negative effect on broiler chickens performance. Krawczyk et al. (2015) used 30\% in laying hens diets without any deterioration in egg production.

A variable but large proportion of the phosphorus $(\mathrm{P})$ in plant material is in form of phytate-P (Sandberg, 2002). The capacity of poultry to utilize phytate-P by endogenous enzymes is very limited (Selle et al., 2012). Approximately $2 / 3$ of total $\mathrm{P}$ in legume seeds are bonded to phytate (Steiner et al., 2007). Phytic acid forming insoluble slats of many mineral ions at intestinal $\mathrm{pH}$, reducing the availability of mineral absorption (Sandberg, 2002; Selle et al., 2000). The presence of phytate also influenced to the reduction of availability of dietary AA and energy (Selle et al., 2000). There are several modes of action to explain the interaction between phytate and AA digestibility (Kies et al., 2001). The binary protein-phytate complex does not undergo enzymatic degradation in the digestive system and excreted in faeces. For the feed industry the most important is phytate interaction with specific amino acids. It has been sown that the most sensitive to the adverse effect of phytate are sulfur-containing AA (Selle et al., 2000).

Whole lupine seeds contain significant content of phytate $\mathrm{P}$ witch limiting the use of lupine in poultry diets (Birk, 1994). In 1991 it was introduced the use of the enzyme phytase in poultry diets to reduce $P$ concentrations in waste from intensive poultry production (Selle et al., 2012). The addition of microbial phytase significantly improves the utilization of phytic phosphorus by poultry, which has been proved in many studies (Simons et al., 1990; Snow et al., 2004). This enzyme has also a positive effect on the digestibility of protein and AA in broilers (Snow et al., 2004) and laying hens (Liebert et al., 2005). The usefulness of exogenous phytate diets for laying hens are still subject to discussion. Studies have shown that supplementation with phytase in the corn-SMB diets improved feed intake, FCR, the mass of eggs and had a positive impact on the digestibility of Ca and P (Jalal and Scheideler, 2001). Later reports suggest that the addition of enzyme did not affect ileal digestibility of AA in hens (Snow et al., 2003).
For the reason of increasing costs of protein feedstuff and increased public concern of environmental pollution making by animal production, there was a need to reduce the amount of nutrient in the waste generated by animals (Angel et al., 2011; Nir et al., 1993). However, studies show that the feed components use in poultry diets are not completely digested in birds organism (Parsons et al., 1997). Protease is used to complement the action of digestive enzymes and improve productive results. Studies show that the addition of protease to diets for broilers resulted in improvement of production performance and better use of energy and nitrogen form feed material (Ghazi et al., 2003). Earlier studies in which the protease was used in diets for broiler chickens showed improvement in FCR and the digestibility of protein and AA (Freitas et al., 2011). The impact of exogenous protease on birds performance are often inconsistent. Differences in the type of the protease and frequent use of multi-enzyme complexes may partially explain the different results (Cowieson, 2008).

The aim of the study was to investigate the interaction between exogenous phytase with protease and protein source in hens diet.

\section{MATERIAL AND METHODS}

\section{Lupin seeds and enzymes}

Seeds of yellow lupine (Lupinus luteus L., Mister cv.) were obtained from the Plant Breeding Stations in Wiatrowo (Poland). The chemical composition of seeds is presented in Table 1. In trial was used phytase (HiPhos) and protease (Ronozyme ProAct) produced by DSM Nutritional Products, Kaiseraugst, Switzerland.

\begin{tabular}{|c|c|c|}
\hline & SBM (g/kg) & YLM \\
\hline Dry matter & 909 & 890 \\
\hline Crude protein $(\mathrm{N} \cdot 6.25)$ & 438 & 415 \\
\hline Crude fat & 30.1 & 52.5 \\
\hline ADF & 6.42 & 24.24 \\
\hline NDF & 9.71 & 28.24 \\
\hline $\mathrm{Ca}$ & 3.0 & 2.95 \\
\hline $\mathrm{P}$ & 6.1 & 7 \\
\hline P-phytic & $3.7(60 \%)$ & $5.25(75 \%)$ \\
\hline \multicolumn{3}{|l|}{ RFO } \\
\hline Raffinose & 11.4 & 11 \\
\hline Stachyose & 44.5 & 449.4 \\
\hline Verbaskose & $0.32(\mathrm{mg} / \mathrm{kg})$ & 25.3 \\
\hline \multicolumn{3}{|l|}{ Total alkaloids } \\
\hline Lupinine & n.d. & 170.89 \\
\hline Sparteine & n.d. & 90.72 \\
\hline
\end{tabular}

SBM - soybean meal, YLM - yellow lupine meal, ADF - acid detergent fibre, NDF - neutral detergent fibre, RFO - raffinose family oligosaccharides, n.d. - not detected 


\section{Birds management}

One hundred sixty Hy-Line Brown hens at the age of 18 weeks were weighed and randomly assigned to 10 treatments, each with 16 birds. Next hens were placed in individual cages with free access to drinking water and fed. The lighting program was $14 \mathrm{~h}$ of light and $10 \mathrm{~h}$ of darkness. All animal procedures were conducted in accordance with the guidelines of the Polish Council of Animal Care. The protocol for this study was approved by the Local Animal Care Committee of the Poznan University of Life Sciences. After 18 weeks of experiment, birds were weighed again. On last day of the experiment, 8 hens from

Table 2: Nutrition value of the diets

\begin{tabular}{lcc}
\hline Components & T1 i T6 & $\begin{array}{c}\text { T2-T5 } \\
\text { T7-T10 }\end{array}$ \\
\hline Metabolizable enrgy (MJ/kg) & 11.63 & 11.05 \\
Crude protein (\%) & 15.4 & 15.3 \\
P-available (\%) & 0.39 & 0.35 \\
Ca (\%) & 3.54 & 3.19 \\
Digestible AA (\%) & & \\
Lys & 0.75 & 0.71 \\
Met+Cys & 0.64 & 0.60 \\
Tryp & 0.16 & 0.15 \\
Treo & 0.53 & 0.50 \\
General AA (\%) & & \\
Arg & 1.18 & 1.18 \\
Val & 0.6 & 0.6 \\
Iso & 0.55 & 0.55 \\
Leu & 1.33 & 1.33 \\
Na (\%) & 0.16 & 0.16 \\
Cl (\%) & 0.16 & 0.16 \\
Phytic-P (g/kg) & 2.35 & 2.35 \\
\hline
\end{tabular}

each group were sacrificed by $\mathrm{CO}_{2}$ gas, according to the recommendations for euthanasia of experimental animals (Close et al., 1997) and left tibiae was taken from them. Tibiae were kept frozen until analysis.

\section{Experimental diets}

Experimental diets were isoenergetic and isonitrogenous and containing about $15 \%$ of crude protein and $11,5 \mathrm{MJ} \mathrm{ME} / \mathrm{kg}$ feed (Table 2). First, five groups contained only soybean meal (SBM) as a protein source. The diets for treatments from 6 to 10 consisted SBM and 20\% of yellow lupine meal (YLM). In six groups used feed enzymes: phytase, protease or both. According to the producer recommendation in diets containing enzymes reduced the level of available phosphorus (50\% reduction) and digestible amino acids - 5\% reduction (Table 3).

\section{Chemical analyses}

For chemical analysis, the representative samples of yellow lupine seeds were ground to pass through a $0.5 \mathrm{~mm}$ sieve. Seeds were analyzed in duplicate for dry matter (DM), crude protein $(\mathrm{CP})$, ether extract (EE), crude fiber $(\mathrm{CF})$, crude ash (CA), acid detergent fiber (ADF) and neutral detergent fiber (NDF) using methods 934.01, 976.05, 920.39, 978.10, 942.05, 973.18 respectively, according to AOAC (2007). The amino acid content was determined using a type AAA-400 Automatic Amino Acid Analyzer employing ninhydrin for post-column derivatization. Before the analysis, samples were hydrolyzed (procedure 994.12; AOAC (2007). Sugars were analyzed according to PN-R-64784 method. Gross energy was determined using an adiabatic bomb calorimeter

Table 3: Composition of the experimental diets ( $\mathrm{g} / \mathrm{kg}$ as fed)

\begin{tabular}{|c|c|c|c|c|c|c|c|c|c|c|}
\hline \multirow[t]{2}{*}{ Components (\%) } & T1 & T2 & T3 & T4 & T5 & T6 & T7 & T8 & T9 & T10 \\
\hline & PC & NC & NC+PRO & $\mathrm{NC}+\mathrm{PHY}$ & $\mathrm{NC}+\mathrm{PRO}+\mathrm{PHY}$ & PC & NC & $\mathrm{NC}+\mathrm{PRO}$ & $\mathrm{NC}+\mathrm{PHY}$ & $\mathrm{NC}+\mathrm{PRO}+\mathrm{PHY}$ \\
\hline Maize & 65.55 & 67.23 & 67.21 & 67.22 & 67.2 & 59.41 & 58.22 & 58.2 & 58.21 & 58.19 \\
\hline SBM (CP 44\%) & 21.25 & & & 21.9 & & 5.4 & & & 8.79 & \\
\hline Yellow lupine (37\%) & - & & & - & & 20 & & & 20 & \\
\hline Limestone 2-4 mm & 4.4 & & & 4.4 & & 4.4 & & & 4.4 & \\
\hline Limestone pon. $2 \mathrm{~mm}$ & 4.09 & & & 3.96 & & 4.05 & & & 3.94 & \\
\hline Soybean oil & 1.88 & & & 0.76 & & 3.81 & & & 3.02 & \\
\hline Monocalcium phosphate & 1.33 & & & 0.38 & & 1.4 & & & 0.41 & \\
\hline Vitamin-mineral premi $x^{1}$ & 0.5 & & & 0.5 & & 0.5 & & & 0.5 & \\
\hline $\mathrm{NaHCO} 3$ & 0.38 & & & 0.46 & & 0.38 & & & 0.31 & \\
\hline DL-Methionine & 0.21 & & & 0.17 & & 0.21 & & & 0.14 & \\
\hline $\mathrm{NaCl}$ & 0.11 & & & 0.13 & & 0.1 & & & 0.15 & \\
\hline L-Lysine & 0.17 & & & 0.09 & & 0.24 & & & 0.08 & \\
\hline L-Valine & 0.07 & & & 0.01 & & - & & & 0.04 & \\
\hline L-Tryptophan & 0.02 & & & 0.01 & & 0.04 & & & 0.01 & \\
\hline L-Treonine & 0.04 & & & - & & 0.08 & & & - & \\
\hline $\begin{array}{l}\text { Protease } \\
\text { (RonozymeProAct) }\end{array}$ & - & - & 0.02 & - & 0.02 & - & - & 0.02 & - & 0.02 \\
\hline Phytase (HiPhose) & - & - & - & 0.02 & 0.02 & - & - & - & 0.02 & 0.02 \\
\hline
\end{tabular}

PC - positive control, NC - negative control, PRO - protease, PHY - phytase

${ }^{1}$ Provided per kg diet: vit. A $10000 \mathrm{IU}$, vit. D3 $2000 \mathrm{IU}$, vit. E $20 \mathrm{mg}$, vit. K3 $1.5 \mathrm{mg}$, vit. B1 1 mg, vit. B2 4 mg, vit. B3 $20 \mathrm{mg}$, vit. B5 8 mg, vit. B6 $1.5 \mathrm{mg}$, vit. B9 $0.8 \mathrm{mg}$, cholin $200 \mathrm{mg}$, Fe $45 \mathrm{mg}$, Mn $90 \mathrm{mg}$, Cu 8 mg, Zn $60 \mathrm{mg}, \mathrm{I} 1 \mathrm{mg}$, Co $0.5 \mathrm{mg}$, Se $0.25 \mathrm{mg}$, antioxidant $15 \mathrm{mg}$, vit. B12 $3300 \mathrm{mg}$, biotin $50 \mathrm{mg}$ 
(KL 12 Mn, Precyzja-Bit PPHU, Poland) standardized with benzoic acid. Mineral composition ( $\mathrm{Ca}, \mathrm{P}, \mathrm{Na}, \mathrm{K}$, $\mathrm{Zn}, \mathrm{Mg}, \mathrm{Cu}, \mathrm{Mn}, \mathrm{Fe}$ ) was analyzed by ICP-OES (P.10I35ICP method) after microwave mineralization. Lupine alkaloids were extracted from flour by trichloroacetic acid and methylene chloride. The determination was provided by gas chromatography method (Shimadzu GC17A) with a capillary column (Phenomenex). Raffinose family oligosaccharides (RFO) were extracted and analyzed by high-resolution gas chromatography as described previously by Zalewski et al. (2001). Phytate content was analyzed according to AOAC (2007) (methods 986.11). The absorbance was measured with Spectrophotometer Marcel at a wavelength of $519 \mathrm{~nm}$ (Table 1).

After defrosting of the left tibia (8 birds per each treatment) and removal of the muscle tissue percentage of tibia ash was determined on a fat-free dry-weight basis, in accordance with AOAC (2005).

\section{Performance and egg quality}

The laying performance was recorded weekly in the period of 18 weeks of an experiment for each of 160 hens. The feed consumption was registered in the same way.

The average egg weight was determined also weekly on the basis of collected all eggs from every hen. In the ninth and seventeenth weeks of the experiment, 30 eggs from each treatment were randomly selected (eggs were selected from all laid during all week). The eggshell quality was determined by taking into consideration the following parameters: thickness, elastic deformation and breaking strength. Eggshell thickness $(\mu \mathrm{m})$ together with shell membranes at the sharp, blunt and equatorial part of the egg using a screw micrometer for this purpose. Examination of the eggshell elastic deformation and the breaking strength were performed using a TA.XT Plus Texture Analyzer (Stable Micro Systems) with a set of suitable starters. Measurement of elastic deformation $(\mu \mathrm{m})$ was carried out with an accuracy of $0.1 \mu \mathrm{m}$ in a three-point measurement of egg after application of three different loads, i.e. $0.50 \mathrm{~kg}$, $1.00 \mathrm{~kg}$ and $1.50 \mathrm{~kg}$. This study allowed to determine the degree of elastic deformation of the eggshell (microns) under the influence of the applied pressure. Evaluation of the breaking strength of eggshell was carried out applying pressure that was gradually increased until eggshell was cracked. This measurement allowed to define force $(\mathrm{N})$, which cause the eggshell break, crush or puncture.

\section{Calculations and statistical analyses}

Two-way analysis of variance was performed using the $\mathrm{R}$ environment (R Development Core Team 2014) and using the "agricolae" package (De Mendiburu 2014) according to the following general model:

$$
Y_{i j}=\mu+\alpha_{i}+\beta_{j}+(\alpha \beta)_{i j}+\varepsilon_{i j} \text {, }
$$

where $Y i j$ is the measured dependent variable, $\mu$ is overall mean, $\alpha \mathrm{i}$ is the effect of $\operatorname{diet} \beta j$ is the effect of the enzyme $(a \beta)$ is the interaction between diet and enzyme and $\varepsilon \mathrm{ij}$ is the random error. Means were compared pairwise using Duncan's multiple range test. In the event of the absence of interactions significances, main effects were discussed. All data are presented as means with a pooled standard error of the mean (SEM).

\section{RESULTS AND DISCUSSION}

The diets used in this experiment had similar crude protein content. Fed with yellow lupine characterized by higher protein content (about 1.3\%). The diets supplemented with YLM contained $1.5 \%$ more crude fat, $2.5 \mathrm{~g} / \mathrm{kg}$ more $\mathrm{ADF}$ and $3.4 \mathrm{~g} / \mathrm{kg}$ NDF. Level of Ca was very similar in all groups and was higher than expected when formulating diets (Table 4).

The egg production during the entire experiment was similar in all groups without significant differences. The egg weight was also on an equal level in all treatments and it was about $58 \mathrm{~g}$. In these two parameters, there was no interaction between the source of protein and inclusion of enzymes. Results in experimental treatments were similar to control groups witch shows that reduced level of available phosphorus and digestible amino acids do not affect laying rate and egg weight. Birds fed different protein source were characterized by similar feed intake and feed conversion ratio during the whole experiment. The inclusion of enzymes also had no effect on these parameters. The FCR was about 1.9-2.0 in all groups (Table 4).

Protein source had no effect of tibia bone ash. Tibia ash was affected by enzymes supplementation. There was an interaction between protein source and enzymes addition. Birds from treatments fed with YLM diets reached highest tibia ash level in a group with phytase addition and in groups with SMB in a group with phytase and protease mix (Table 5). Reducing the level of available phosphorus and amino acids caused a decrease in ash content of the tibia bones of birds from group 7 compared to the control group.

Shell thickness in eggs from part I was significantly different between groups. The inclusion of enzymes improved the thickness of the shell. There was an interaction between protein source and enzyme inclusion. Thickest shell characterized eggs from group fed diets with a mix of phytase and protease (Table 5). It was an interaction between experimental factors in shell breaking strength. Stronger 
eggshell was laid by hens from groups fed with the inclusion of YLM. Addition of phytase had a positive impact on increasing the strength of eggshell (Table 5). Only inclusion of enzymes affected significantly on shell elastic deformation in part I of eggs. Eggs from hens fed diets with inclusion of protease and phytase mix were most resistant to elastic deformation (Table 5). In eggs, there were no significant differences between groups in all egg parameter (Table 6).

The obtained results suggest that a $20 \%$ addition of yellow lupine did not affect egg laying performance and egg weight which is in agreement with previous research (Krawczyk et al., 2015; van Barneveld, 1999). Alternative research has reported that the application of $25 \%$ sweet lupine seeds to diets had a significant impact on reducing the weight of the eggs (Hammershoj and Steenfeldt, 2005). Above authors suggested that decrees in egg weight were caused by methionine deficiency. However, in this study, the methionine content was corrected after the addition of lupine. In the present study, the levels of amino acids in diets containing SMB and those with the addition of yellow lupine have been aligned. Besides, these differences may result from the use of different cultivar of lupine (Nalle et al., 2011). It could be speculated that the reduction in egg weight after YLM addition was caused by a reduction in AME of diets. Kaczmarek et al. (2015) found that 20\% inclusion of YLM for broilers chickens, reduces dietary $\mathrm{AME}_{\mathrm{N}}$ for $0.8 \mathrm{MJ} / \mathrm{kg}$ of diet. Above authors speculated, that lupin cultivars and species may differ with regard to their oligosaccharide and NSP content and may be characterized by different water extract viscosity, which may undesirably affect $\mathrm{AME}_{\mathrm{N}}$, crude fat digestibility and, subsequently, birds performance.

A previous study (Kaczmarek et al., 2015) shown that effectiveness of phytase does not only depend on used plant protein. Results of our study seem to confirm this thesis. Almost in all group with low P level diets inclusion

Table 4: Chemical composition of diets

\begin{tabular}{|c|c|c|c|c|c|c|c|c|}
\hline Treatment & Protein source & Enzyme & Crude protein (\%) & Crude fat (\%) & ADF $(g / k g)$ & NDF $(g / k g)$ & $\mathrm{Ca}(\%)$ & Phytic-P \\
\hline $\mathrm{PC}$ & SBM & $\mathrm{NO}$ & 15.8 & 2.78 & 3.72 & 6.69 & 4.43 & 2.84 \\
\hline 2 & & NO & 16.38 & 2.11 & 3.9 & 7.34 & 4.12 & 3.33 \\
\hline 3 & & PROT & 16.14 & 2.17 & 3.73 & 7.4 & 4.23 & 3.19 \\
\hline 4 & & PHY & 15.84 & 2.34 & 3.3 & 7.29 & 3.75 & 2.68 \\
\hline 5 & & PROT+PHY & 16.68 & 2.07 & 3.28 & 6.88 & 4.41 & 2.67 \\
\hline PC & YLM & NO & 16.54 & 4.12 & 6.16 & 9.85 & 4.66 & 2.18 \\
\hline 7 & & NO & 17.9 & 4.04 & 7.27 & 10.35 & 4.17 & 2.79 \\
\hline 8 & & PROT & 17.74 & 3,0 & 7.31 & 10.84 & 3.81 & 3.25 \\
\hline 9 & & PHY & 17.61 & 3.5 & 6.38 & 10.1 & 4.17 & 3.32 \\
\hline 10 & & PROT+PHY & 17.4 & 3.78 & 6.24 & 11.7 & 4.21 & 2.6 \\
\hline
\end{tabular}

Table 5: Laying rate, egg weight, FI, FCR and bone ash of birds fed with experimental diets

\begin{tabular}{|c|c|c|c|c|c|c|c|}
\hline Treatment & Protein source & Enzyme & Laying rate (\%) & Egg weight (g) & $\mathrm{FI}(\mathrm{g})$ & FCR & Bone ash (\%) \\
\hline $\mathrm{PC}$ & SBM & NO & 91.2 & 60.12 & 78.4 & 1.92 & 30.35 \\
\hline 2 & & NO & 90.6 & 58.87 & 112 & 1.98 & $28.73^{a b c}$ \\
\hline 3 & & PROT & 90.32 & 59.68 & 112.6 & 1.96 & $28.72^{a b c}$ \\
\hline 4 & & PHY & 89.31 & 59 & 109.3 & 1.95 & $27.41^{b c}$ \\
\hline 5 & & $\mathrm{PROT}+\mathrm{PHY}$ & 90.15 & 58.33 & 112.8 & 2.04 & $30.46^{a}$ \\
\hline PC & YLM & NO & 89.63 & 57.89 & 77.95 & 2.09 & $33.24^{*}$ \\
\hline 7 & & NO & 91.6 & 58.45 & 114.9 & 2.02 & $26.71^{\text {c* }}$ \\
\hline 8 & & PROT & 88.51 & 57.6 & 109.2 & 2 & $28.69^{a b c}$ \\
\hline 9 & & PHY & 90 & 58.21 & 112.2 & 1.97 & $30.4^{a}$ \\
\hline \multirow[t]{10}{*}{10} & & $\mathrm{PROT}+\mathrm{PHY}$ & 90.68 & 57.41 & 112.6 & 2.05 & $30.33^{\mathrm{ab}}$ \\
\hline & & SEM & 0.36 & 0.3035 & 0.7054 & 0.01 & 0.3295 \\
\hline & SBM & & $90.1^{\mathrm{a}}$ & $58.97^{a}$ & $111.7^{\mathrm{a}}$ & $1.98^{\mathrm{a}}$ & $28.84^{a}$ \\
\hline & YLM & & $90.2^{a}$ & $57.92^{\mathrm{a}}$ & $112.2^{\mathrm{a}}$ & $2.01^{a}$ & $28.97^{a}$ \\
\hline & & NO & $91.1^{\mathrm{a}}$ & $58.66^{a}$ & $113.5^{\mathrm{a}}$ & $1.99^{a}$ & $27.66^{b}$ \\
\hline & & PROT & $89.41^{a}$ & $58.64^{a}$ & $110.0^{\mathrm{a}}$ & $1.98^{a}$ & $28.7^{\mathrm{ab}}$ \\
\hline & & PHY & $89.66^{a}$ & $58.61^{a}$ & $110.7^{\mathrm{a}}$ & $1.96^{a}$ & $28.81^{\mathrm{ab}}$ \\
\hline & & PROT+PHY & $90.42^{a}$ & $57.87^{\mathrm{a}}$ & $112.7^{a}$ & $2.04^{a}$ & $30.34^{a}$ \\
\hline & PROTEIN & & 0.89 & 0.09 & 0.7 & 0.3 & 0.78 \\
\hline & & ENZYMES & 0.35 & 0.75 & 0.44 & 0.23 & $<0.05$ \\
\hline INTERACTION & & & 0.5 & 0.79 & 0.33 & 0.98 & $<0.05$ \\
\hline
\end{tabular}

FI - feed intake, FCR - feed conversion ratio, SBM - soybean meal, YLM - yellow lupine meal, NO - no enzyme added, PROT - protease, PHY - phytase, PC - positive control 
Kubiś, et al.

Table 6: Shell thickness, shell breaking strength and elastic deformation of eggs from birds fed experimental diets. I and II part

\begin{tabular}{|c|c|c|c|c|c|c|c|c|}
\hline \multirow[t]{2}{*}{ Treatment } & \multirow[t]{2}{*}{ Protein source } & \multirow[t]{2}{*}{ Enzyme } & \multicolumn{2}{|c|}{ Shell thickness $(\mu \mathrm{m})$} & \multicolumn{2}{|c|}{ Shell breaking strength $(\mathrm{N})$} & \multicolumn{2}{|c|}{ Shell elastic deformation $(\mu)$} \\
\hline & & & I & II & I & II & I & II \\
\hline PC & SBM & NO & $0.36^{*}$ & 0.37 & $4.07^{\star}$ & 4.34 & $0.35^{\star}$ & 0.37 \\
\hline 2 & SBM & NO & $0.35^{\mathrm{de} *}$ & 0.35 & $3.89^{c *}$ & 4.21 & $0.35^{\text {de } \star}$ & 0.35 \\
\hline 3 & & PROT & $0.36^{\mathrm{cd}}$ & 0.34 & $4.94^{\mathrm{ab}}$ & 4.28 & $0.36^{\mathrm{cd}}$ & 0.34 \\
\hline 4 & & PHY & $0.37^{\mathrm{bc}}$ & 0.32 & $4.83^{\mathrm{ab}}$ & 4.58 & $0.37^{\mathrm{bc}}$ & 0.32 \\
\hline 5 & & $\mathrm{PROT}+\mathrm{PHY}$ & $0.39^{a}$ & 0.34 & $3.61^{c}$ & 4.47 & $0.39^{a}$ & 0.34 \\
\hline PC & YLM & NO & $0.39^{*}$ & 0.34 & 3.61 & $4.47^{\star}$ & 0.41 & 0.35 \\
\hline 7 & YLM & NO & $0.37^{\mathrm{bc} *}$ & 0.33 & $4.72^{b}$ & $4.3^{*}$ & $0.37^{b c}$ & 0.33 \\
\hline 8 & & PROT & $0.35^{e}$ & 0.34 & $3.89^{c}$ & 4.58 & $0.34^{e}$ & 0.34 \\
\hline 9 & & $\mathrm{PHY}$ & $0.37^{b c}$ & 0.34 & $4.79^{\mathrm{ab}}$ & 4.57 & $0.37^{b c}$ & 0.34 \\
\hline \multirow[t]{10}{*}{10} & & $\mathrm{PROT}+\mathrm{PHY}$ & $0.38^{\mathrm{ab}}$ & 0.34 & $5.36^{a}$ & 4.48 & $0.38^{a b}$ & 0.34 \\
\hline & & SEM & 0.002 & 0.003 & 0.07 & 0.003 & 0.002 & 0.003 \\
\hline & SBM & & $0.37^{a}$ & $0.34^{a}$ & $4.32^{b}$ & $4.37^{a}$ & $0.37^{a}$ & $0.34^{a}$ \\
\hline & YLM & & $0.38^{a}$ & $0.34^{a}$ & $4.69^{a}$ & $4.49^{a}$ & $0.37^{a}$ & $0.34^{a}$ \\
\hline & & NO & $0.36^{c}$ & $0.34^{a}$ & $4.3^{\mathrm{b}}$ & $4.25^{a}$ & $0.36^{c}$ & $0.34^{a}$ \\
\hline & & PROT & $0.35^{c}$ & $0.34^{a}$ & $4.41^{b}$ & $4.44^{\mathrm{a}}$ & $0.35^{c}$ & $0.34^{a}$ \\
\hline & & $\mathrm{PHY}$ & $0.37^{b}$ & $0.33^{a}$ & $4.81^{a}$ & $4.57^{a}$ & $0.37^{b}$ & $0.33^{a}$ \\
\hline & & $\mathrm{PROT}+\mathrm{PHY}$ & $0.39^{a}$ & $0.34^{a}$ & $4.48^{\mathrm{ab}}$ & $4.47^{a}$ & $0.39^{a}$ & $0.34^{a}$ \\
\hline & PROTEIN & & 0.81 & 0.46 & $<0.0001$ & 0.52 & 0.85 & 0.46 \\
\hline & & ENZYMES & $<0.0001$ & 0.83 & $<0.0001$ & 0.55 & $<0.0001$ & 0.83 \\
\hline INTERACTION & & & $<0.0001$ & 0.10 & $<0.0001$ & 0.89 & $<0.0001$ & 0.10 \\
\hline
\end{tabular}

SBM - soybean meal, YLM - yellow lupine meal, NO - no enzyme added, PROT - protease, PHY - phytase, PC - positive control

of enzymes improve the content of crude ash in tibia bone. Exogenous phytase caused dephosphorylation of inositol hexaphosphate, thanks to which minerals $(\mathrm{P}, \mathrm{Ca}$ ) previously bound in the phytate mineral complexes were released. Released minerals could be absorbed in the digestive tract and then participate in the bone mineralization process. (Qian et al., 1996). Reducing the level of available phosphorus in diets $\mathrm{f}$ in groups fed with the addition of YLM resulted in a significant decrease in ash content in the bones. This may be due to the fact that the yellow lupine seeds like other legumes contain $75 \%$ of the phosphorus bound in phytate mineral complex which is no available to the animal organism. After the addition of the phytase, the negative effects of phosphorus reduction subsided. The addition of phytase to the diet with SBM as the only source of protein did not affect the increase of the ash content in the tibia. This is confirmed in other studies (Hughes et al., 2009) in which the authors suggest that this is related to the length of the laying period (36 weeks of age and 18 weeks of laying period) and ability of the bird to utilize dietary P. In these studies, significant differences in bone ash content was observed only in the 61 weeks of age. Eggs laid by hens fed with the addition of yellow lupine characterized by a higher mechanical strength of the eggshell. According to Jalal and Scheideler (2001) source of protein have no effect on this parameter. The addition of phytase had a positive influence on the mechanical strength of the shell, shell thickness and elastic deformation of eggshells. This may be related to the breakdown of phytate-mineral complexes, which resulted in the higher availability of minerals that affect the construction of the shell (Selle et al., 2006). Use of enzymes improved shell thickness and shell breaking strength, but the enzymes addition was more pronounce in SBM than YLM diets which resulted in significant protein source $\mathrm{x}$ enzyme interaction $(\mathrm{P}<0.05)$. The location of phytate salts in raw materials varies among sources (Steiner et al. 2007). In cereals such as maize, around $90 \%$ of phytate is located within the germ portion of the kernel, but in soybeans, phytate-P is associated with protein bodies, usually distributed throughout the seed (O'Dell et al. 1972; O'Dell and De Boland 1976). Based on above could be hypothesized that use of protease alone or in combination with phytase, degraded protein bodies and released some part of encapsulated phytate. According to Selle et al. (2006), proteases could degrade protein bodies and in that way improve the availability of phytate for hydrolysis by phytase. Additionally, Kies et al. (2006), showed that exogenous phytase prevents the creation of phytateprotein complexes. Insoluble protein-phytate complexes are formed at low $\mathrm{pH}$, as present in the gizzard of birds and this may affect protein digestibility significantly.

It is unknown why there were no differences in shell quality parameter in the seventeenth weeks of the experiment. It could be speculated that with the age of the bird's diet was utilized better, resulting in higher $\mathrm{P}$ and $\mathrm{Ca}$ absorption because of higher digestive tract capacity.

\section{Authors' contributions}

S. A. K and A. R. designed and directed the project; M. K., L. L., S. N., M. H. performed the experiments; M.K and S. A. K. wrote the article. 


\section{REFERENCES}

Angel, C.R., W. Saylor, S. L Vieira. and N. Ward. 2011. Effects of a monocomponent protease on performance and protein utilization in 7 to 22-day-old broiler chickens. Poult. Sci. 90: 2281-2286.

AOAC. 2007. Official Methods of Analysis of the Association Official Analytical Chemists. $18^{\text {th }}$ ed. AOAC, Arlington USA.

Birk, Y. 1994. Antinutritive Factors (ANFs) in Lupins and in Other Legume Seeds. Advances in Lupin Research. Proceedings of $7^{\text {th }}$ International Lupin Conference, ISA Press, Evora, Portugal. pp. 424-429.

Close, B., K. Banister, V. Baumans, E. M. Bernoth, N. Bromage, J. Bunyan, J. Erhardt, P. Flecknell, N. Gregory, H. Hackbarth, D. Morton. and C. Warwick. 1997. Recommendations for euthanasia of experimental animals: Part 2. DGXT of the European Commission. Lab. Anim. 31: 1-32.

Cowieson, A. J. 2008. The effect of phytase, protease and carbohydrase on ileal amino acid digestibility of corn/soy diets for broilers: Complimentary mode of action? Poult. Sci. 87: 64-64.

Freitas, D.M., S. L. Vieira, C. R. Angel, A. Favero. and A. Maiorka. 2011. Performance and nutrient utilization of broilers fed diets supplemented with a novel mono-component protease. J. Appl. Poult. Res. 20: 322-334.

Ghazi, S., J. A. Rooke. and H. Galbraith. 2003. Improvement of the nutritive value of soybean meal by protease and a-galactosidase treatment in broiler cockerels and broiler chicks. Br. Poult. Sci. 44: 410-418.

Hammershoj, M. and S. Steenfeldt. 2005. Effects of blue lupin (Lupinus angustifolius) in organic layer diets and supplementation with foraging material on egg production and some egg quality parameters. Poult. Sci. 84: 723-733.

Hughes, A.L., J. P. Dahiya, C. L. Wyatt. and H. L. Classen. 2009. Effect of quantum phytase on nutrient digestibility and bone ash in white leghorn laying hens fed corn-soybean meal-based diets. Poult. Sci. 88: 1191-1198.

Jahanian, R. and E. Rasouli. 2016. Effect of extrusion processing of soybean meal on ileal amino acid digestibility and growth performance of broiler chicks. Poult. Sci. 95: 2871-2878.

Jalal, M.A. and S. E. Scheideler. 2001. Effect of supplementation of two different sources of phytase on egg production parameters in laying hens and nutrient digestiblity. Poult. Sci. 80: 1463-1471.

Kaczmarek, S.A., A. J. Cowieson, M. Hejdysz. and A. Rutkowski. 2015. Microbial phytase improves performance and bone traits in broilers fed diets based on soybean meal and containing lupin meal. Anim. Prod. Sci. http://dx.doi.org/10.1071/AN14856.

Kaczmarek, S.A., M. Kasprowicz-Potocka, M. Hejdysz, R Mikuła. and A. Rutkowski. 2014. The nutritional value of narrow-leafed lupin (Lupinus angustifolius) for broilers. J. Anim. Feed Sci. 23: 160-166.

Kies, A.K., K. H. F. van Hemert. and W. C. Sauer. 2001. Effect of phytase on protein and amino acid digestibility and energy utilisation. Worlds Poult. Sci. J. 57: 109-126.

Kocher, A., M. Choct, R. J. Hughes. and J. Broz. 2000. Effect of food enzymes on utilisation of lupin carbohydrates by broilers. Br. Poult. Sci. 41: 75-82.

Krawczyk, M., M. Przywitowski. and D. Mikulski. 2015. Effect of yellow lupine (L. luteus) on the egg yolk fatty acid profile, the physicochemical and sensory properties of eggs, and laying hen performance. Poult. Sci. 94: 1360-1367.

Liebert, F., J. K. Htoo. and A. Sünder. 2005. Performance and nutrient utilization of laying hens fed low-phosphorus corn-soybean and wheat-soybean diets supplemented with microbial phytase. Poult. Sci. 84: 1576-1583.
Mikulski, D., J. Jankowski, Z. Zdunczyk, J. Juskiewicz. and B. A. Slominski. 2012. The effect of different dietary levels of rapeseed meal on growth performance, carcass traits, and meat quality in turkeys. Poult. Sci. 91: 215-223.

Nalle, C. L., V. Ravindran. and G. Ravindran. 2011. Nutritional value of narrow-leafed lupin (Lupinus angustifolius) for broilers. Br. Poult. Sci. 52: 775-781.

Nir, I., Z. Nitsan. and M. Mahagna. 1993. Comparative growth and development of the digestive organs and of some enzymes in broiler and egg type chicks after hatching. Br. Poult. Sci. 34: 523-532.

O'Dell, B. L. and A. De Boland. 1976. Complexation of phytate with proteins and cations in corn germ and oil seed meals. J. Agric. Food Chem. 24(4): 804-808.

O'Dell, B. L., A. R. De Boland. and S. R. Koirtyohann. 1972. Distribution of phytate and nutritionally important elements among the morphological components of cereal grains. J. Agric. Food Chem. 20(3): 718-723.

Olkowski, A. A., B. I. Olkowski, R. Amarowicz. and H. L. Classen. 2001. Adverse effects of dietary lupine in broiler chickens. Poult. Sci. 80: 621-625.

Olkowski, B.I., H. L. Classen, C. Wojnarowicz. and A. A. Olkowski. 2005. Feeding high levels of lupine seeds to broiler chickens: Plasma micronutrient status in the context of digesta viscosity and morphometric and ultrastructural changes in the gastrointestinal tract. Poult. Sci. 84: 1707-1715.

Orda, J., D. Jamroz, A. Wiliczkiewicz, T. Wertelecki, J. Skorupinska. and J. Broz. 2004. Effects of increased dietary inclusion of yellow lupins and enzyme supplementation on performance, ileal digestibility of nutrients and microbial status of large intestine in broiler chickens. Arch. Geflugelkunde 70: 14-21.

Parsons, C., F. Castanon. and Y. Han. 1997. Protein and amino acid quality of meat and bone meal. Poult. Sci. 76: 361-368.

Qian, H., E. T. Kornegay. and D. M. Denbow. 1996. Phosphorus equivalence of microbial phytase in turkey diets as influenced by calcium to phosphorus ratios and phosphorus levels. Poult. Sci. 75: 69-81.

Ravindran, V., M. R. Abdollahi. and S. M. Bootwalla. 2014. Nutrient analysis, metabolizable energy, and digestible amino acids of soybean meals of different origins for broilers. Poult. Sci. 93: 2567-2577.

Rutkowski, A., S. A. Kaczmarek, M. Hejdysz, S. Nowaczewski. and D. Jamroz. 2015. Concentrates made from legume seeds (Lupinus Angustifolius, Lupinus luteus and Pisum sativum) and rapeseed meal as protein sources in laying hen diets. Ann. Anim. Sci. 15: 129.

Sandberg, A.S. 2002. Bioavailability of minerals in legumes. Br. J. Nutr. 88: 281-285.

Selle, P.H., A. J. Cowieson, N. P. Cowieson. and V. Ravindran. 2012. Protein-phytate interactions in pig and poultry nutrition: $A$ reappraisal. Nutr. Res. Rev. 25: 1-17.

Selle, P.H., V. Ravindran, W L. Bryden. and T. Scott. 2006. Influence of dietary phytate and exogenous phytase on amino acid digestibility in poultry: A review. J. Poult. Sci. 43: 89-103.

Selle, P.H., V. Ravindran, A. Caldwell. and W. L. Bryden. 2000. Phytate and phytase: Consequences for protein utilisation. Nutr. Res. Rev. 13: 255-278.

Simons, P.C.M., H. A. J. Versteegh, A. W. Jongbloed, P. A. Kemme, P. Slump, K. D. Bos, M. G. E. Wolters, R. F. Beudeker. and G. J. Verschoor. 1990. Improvement of phosphorus availability by microbial phytase in broilers and pigs. Br. J. Nutr. 64: 525-540.

Smulikowska, S., P. Konieczka, J. Czerwinski, A. Mieczkowska. and J. Jankowiak. 2014. Feeding broiler chickens with practical diets containing lupin seeds (L. angustifolius or L. luteus): Effects of 
incorporation level and mannanase supplementation on growth performance, digesta viscosity, microbial fermentation and gut morphology. J. Anim. Feed Sci. 23: 64-72.

Snow, J., M. Douglas. and C. Parsons. 2003. Phytase effects on amino acid digestibility in molted laying hens. Poult. Sci. 82: 474-477.

Snow, J. L., D. H. Baker. and C. M. Parsons. 2004. Phytase, citric acid, and 1a-hydroxycholecalciferol improve phytate phosphorus utilization in chicks fed a corn-soybean meal diet. Poult. Sci. 83: 1187-1192.

Steiner, T., R. Mosenthin, B. Zimmermann, R. Greiner. and S. Roth. 2007. Distribution of phytase activity, total phosphorus and phytate phosphorus in legume seeds, cereals and cereal byproducts as influenced by harvest year and cultivar. Anim. Feed Sci. Technol. 133: 320-334. van Barneveld, R. J. 1999. Understanding the nutritional chemistry of lupin (Lupinus spp.) seed to improve livestock production efficiency. Nutr. Res. Rev. 12: 203-230.

Viveros, A., C. Centeno, I. Arija. and A. Brenes. 2007. Cholesterollowering effects of dietary lupin (Lupinus albus var Multolupa) in chicken diets. Poult. Sci. 86: 2631-2638.

Zalewski, K., L. Lahuta. and M. Horbowicz. 2001. The effect of soil drought on the composition of carbohydrates in yellow lupin seeds and triticale kernels. Acta Physiol. Plant. 23: 73-78.

Zdunczyk, Z., J. Jankowski, A. Rutkowski, E. Sosnowska, A. Drazbo, P. Zdunczyk. and J. Juskiewicz. 2014. The composition and enzymatic activity of gut microbiota in laying hens fed diets supplemented with blue lupine seeds. Anim. Feed Sci. Technol. 191: 57-66. 